\title{
Distinguishing adult-onset asthma from COPD: a review and a new approach
}

This article was published in the following Dove Press journal:

International Journal of COPD

9 September 2014

Number of times this article has been viewed

\author{
Michael J Abramson' \\ Jennifer L Perret ${ }^{2,3}$ \\ Shyamali C Dharmage ${ }^{2}$ \\ Vanessa M McDonald ${ }^{4}$ \\ Christine F McDonald ${ }^{3}$ \\ 'School of Public Health and \\ Preventive Medicine, Monash \\ University, ${ }^{2}$ Centre for Epidemiology \\ and Biostatistics, University of \\ Melbourne, Melbourne, Australia; \\ ${ }^{3}$ Department of Respiratory and \\ Sleep Medicine, Austin Health, \\ Heidelberg, Australia; ${ }^{4}$ Priority \\ Research Centre for Asthma and \\ Respiratory Disease, University of \\ Newcastle, Newcastle, Australia
}

Correspondence: Michael J Abramson School of Public Health and Preventive Medicine, Monash University, The Alfred Centre, Melbourne, VIC 3004, Australia

Tel +6I 399030573

Fax +6I 399030556

Email michael.abramson@monash.edu
Abstract: Adult-onset asthma and chronic obstructive pulmonary disease (COPD) are major public health burdens. This review presents a comprehensive synopsis of their epidemiology, pathophysiology, and clinical presentations; describes how they can be distinguished; and considers both established and proposed new approaches to their management. Both adult-onset asthma and COPD are complex diseases arising from gene-environment interactions. Early life exposures such as childhood infections, smoke, obesity, and allergy influence adult-onset asthma. While the established environmental risk factors for COPD are adult tobacco and biomass smoke, there is emerging evidence that some childhood exposures such as maternal smoking and infections may cause COPD. Asthma has been characterized predominantly by Type 2 helper T cell (Th2) cytokine-mediated eosinophilic airway inflammation associated with airway hyperresponsiveness. In established COPD, the inflammatory cell infiltrate in small airways comprises predominantly neutrophils and cytotoxic $\mathrm{T}$ cells (CD8 positive lymphocytes). Parenchymal destruction (emphysema) in COPD is associated with loss of lung tissue elasticity, and small airways collapse during exhalation. The precise definition of chronic airflow limitation is affected by age; a fixed cut-off of forced expiratory volume in 1 second/forced vital capacity leads to overdiagnosis of COPD in the elderly. Traditional approaches to distinguishing between asthma and COPD have highlighted age of onset, variability of symptoms, reversibility of airflow limitation, and atopy. Each of these is associated with error due to overlap and convergence of clinical characteristics. The management of chronic stable asthma and COPD is similarly convergent. New approaches to the management of obstructive airway diseases in adults have been proposed based on inflammometry and also multidimensional assessment, which focuses on the four domains of the airways, comorbidity, self-management, and risk factors. Short-acting beta-agonists provide effective symptom relief in airway diseases. Inhalers combining a longacting beta-agonist and corticosteroid are now widely used for both asthma and COPD. Written action plans are a cornerstone of asthma management although evidence for self-management in COPD is less compelling. The current management of chronic asthma in adults is based on achieving and maintaining control through step-up and step-down approaches, but further trials of back-titration in COPD are required before a similar approach can be endorsed. Long-acting inhaled anticholinergic medications are particularly useful in COPD. Other distinctive features of management include pulmonary rehabilitation, home oxygen, and end of life care.

Keywords: chronic obstructive pulmonary disease, diagnosis, management, adults, inflammometry

\section{Introduction}

Asthma and chronic obstructive pulmonary disease (COPD) are both chronic inflammatory diseases of the airways that induce airflow limitation. Asthma often starts 
in childhood, in such cases being commonly associated with allergies. It may remit and recur in adulthood, ${ }^{1}$ or symptoms may continue throughout adolescence into adult life. Asthma may also develop de novo at any age, in some cases apparently triggered by a severe respiratory tract infection. ${ }^{2}$ Asthma is characterized by intermittent and variable wheeze, chest tightness, and shortness of breath. COPD becomes apparent in middle to older age, but is now considered to have origins in early life. ${ }^{3}$ COPD is characterized predominantly by gradually increasing dyspnea. Clinical features common to both include cough, mucus hypersecretion, wheeze, and intermittent exacerbations or "flare-ups".

Asthma and COPD are usually considered to be distinct diseases and up until recently were associated with distinct approaches to diagnosis and management. ${ }^{4-6}$ However, it has become increasingly evident that differentiating asthma from COPD can be difficult, particularly in older populations. This is because older patients frequently exhibit features of more than one disease. ${ }^{7-9}$ This is commonly referred to as asthmaCOPD overlap, and includes the coexistence of asthma, and emphysema or chronic bronchitis. ${ }^{10,11}$

Distinguishing between adult-onset asthma and COPD is a vigorously debated topic in respiratory medicine. This review compares and contrasts the current evidence on epidemiology, pathophysiology, diagnosis, and management of these two diseases.

\section{Epidemiology of asthma and COPD Burden of disease related to asthma and COPD}

Adult-onset asthma and COPD have become much more common in the recent past and are now major public health problems in many countries. ${ }^{12,13}$ Asthma prevalence has increased in epidemic proportions over the last few decades and continues to rise in most parts of the world. ${ }^{13}$ COPD burden is also set to increase during the next few decades, especially with the aging of the population and continued use of tobacco.

Adult-onset asthma differs from childhood asthma in that it is more often nonatopic and severe and has a lower remission rate. ${ }^{14}$ Although asthma has a relatively low mortality in younger adults, in the elderly, it is associated with substantial morbidity, healthcare utilization, ${ }^{15}$ and mortality. ${ }^{16}$ The prevalence of current asthma in Australian adults is around 10\%, which includes both childhood and adult-onset disease. ${ }^{17}$ Substantial variation in the prevalence of adult asthma across 25 countries has been reported by the European Community Respiratory Health Survey, the largest international study of asthma in young adults. ${ }^{18}$ This variation has been attributed more to differences in potential environmental risk factors than to genetics, as variation was observed even across countries with similar ethnic populations.

COPD is the fourth leading cause of death worldwide and expected to be the third leading cause by $2030 .{ }^{19}$ However a systematic review of the health burden of COPD has shown that mortality has now started to decrease for men in some Western countries, whereas rates have continued to rise or plateau for women. ${ }^{20}$

There is substantial variation in COPD prevalence across countries, and the use of various diagnostic classifications has been suggested as one reason. However, the findings of the Burden of Obstructive Lung Disease Study (BOLD) that used similar methodology across 12 countries suggest otherwise. BOLD estimated overall $11.8 \%$ of middleaged to elderly men and $8.5 \%$ of similarly aged women as having COPD, identified using spirometric criteria, ${ }^{12}$ but the prevalence varied significantly across study centers. Perhaps not surprisingly, the variation followed a similar geographical distribution to the variation in the prevalence of smoking.

Both diseases have substantial economic and social costs. These include both direct costs related to medical management and indirect costs related to disability, lost revenue from not attending work, and caring for patients. In Europe, $6 \%$ of the health budget is used for direct costs related to respiratory diseases, just over half of which are related to COPD. ${ }^{21}$ A recent study in the UK found the annual per patient cost of COPD management, excluding medications, to be $£ 2,108$ for all patients, while this ranged from $£ 1,523$ to $£ 3,396$ for mild to severe COPD. ${ }^{22}$ Annual per person costs for an adult with asthma have also been found to vary from $\$ 2,646$ to $\$ 12,813$ USD for mild to severe asthma in a sample of patients in California. ${ }^{23}$

\section{Definitions used in epidemiology}

The demarcation between childhood-onset and adult-onset asthma is somewhat arbitrary, but adult-onset has been defined as from as young as 16 years. ${ }^{24}$ The combination of airway hyperresponsiveness (AHR) and current asthma symptoms is a reliable indicator of clinically important asthma across age groups. ${ }^{25}$ However, the presence of wheeze alone within the last 12 months has been used by many large epidemiological studies to determine current asthma prevalence regardless of the age of onset. ${ }^{26-28}$

Post-bronchodilator (BD) airflow obstruction is fundamental to the definition of COPD. ${ }^{21} \mathrm{~A}$ clinical diagnosis 
of COPD also relies on the presence of coexistent symptoms and risk factors. ${ }^{21}$ However, epidemiological studies have mainly adopted only the spirometric criterion. ${ }^{12,29,30}$

The Global initiative for Obstructive Lung Disease (GOLD) endorses the spirometry criterion of post-BD forced expiratory volume in 1 second $\left(\mathrm{FEV}_{1}\right)$ /forced vital capacity (FVC) less than 0.70 , with spirometric staging by the BOLD study also including an $\mathrm{FEV}_{1}$ less than $80 \%$ predicted. ${ }^{12,29}$ This fixed cut-off is susceptible to the risk of overdiagnosing a substantial number of older symptomatic individuals as having COPD, ${ }^{31}$ which might contribute to the relative underdiagnosis of asthma in the elderly, particularly females. An alternative approach has been proposed to overcome this problem, whereby the cut-off is based on the lower limit of predicted normal. ${ }^{32}$ This cut-off assumes the "usual progressive" lung function decline of COPD is greater than the physiological age-related decline of the $\mathrm{FEV}_{1} / \mathrm{FVC}$ ratio.

\section{Risk factors for adult-onset asthma and COPD}

Both asthma and COPD are acknowledged as complex diseases related to both genetic and environmental risk factors, but environment seems to play the stronger role. Although asthma has a high heritability, genetic studies to date have been able to explain only a small proportion of the variability. The evidence for a genetic etiology of adultonset asthma is even less convincing, with neither family history nor atopy being clearly linked to this phenotype. ${ }^{14}$ Homozygous $\alpha$-1-antitrypsin deficiency (PiZZ) is the most common genetic risk factor for COPD, and the odds are also increased among heterozygous alpha-1-antitrypsin deficient (PiMZ) smokers. ${ }^{30}$ Very recently, an interaction has been demonstrated between the PiMZ genotype and occupational exposures to vapors, gas, dust, and fumes, on annual decline in lung function. ${ }^{33}$

A growing body of evidence suggests that early life and childhood factors are important in both adult-onset asthma and COPD. ${ }^{34,35}$ This concept is based on data that show associations between various adverse perinatal outcomes and harmful environmental stimuli, with slowing of lung function growth for susceptible children and adolescents. ${ }^{36-39}$ This effectively reduces peak lung function and impacts on the corresponding trajectory of lung function decline in adulthood. Such prenatal and postnatal factors include intrauterine growth restriction, prematurity, second-hand smoke exposure, air pollution, recurrent respiratory infections, and personal smoking. ${ }^{35}$
Occupational exposures are major preventable risk factors for adult-onset asthma. ${ }^{40,41}$ During an individual's "productive working years", occupational asthma can frequently be overlooked, and from middle-age, symptoms may be attributed erroneously to COPD. A systematic inquiry into past and current occupational exposures is often required to confirm the diagnosis, as asthma might be still present after the exposure ceases. ${ }^{4}$ A combined effect of occupational exposure and personal smoking has been shown to further increase the likelihood of airflow obstruction. ${ }^{42}$

Nonoccupational risk factors for adult-onset asthma are heterogeneous and play a lesser role. These can be either childhood or adult exposures. Longitudinal studies have shown that childhood infections, tobacco smoke exposure, obesity, and allergic phenotypes influence adult-onset asthma. ${ }^{43}$ In addition, female reproductive history, especially contraception, ${ }^{44}$ menopause, ${ }^{45}$ and hormone replacement therapy ${ }^{46}$ is emerging as a strong risk factor for adultonset asthma.

The patterns of COPD risk factors differ between geographical areas. In high- and middle-income countries, tobacco smoke is the biggest risk factor. However, in lowincome countries, exposure to indoor air pollution, such as through the use of biomass fuels for cooking and heating, and occupational exposures, are more important. ${ }^{47,48}$ Personal tobacco smoking is the principal risk factor for COPD in industrialized countries; however, a meta-analysis has also shown an independent association for second-hand tobacco smoke exposure, which may be causal. ${ }^{49}$ Traffic-related air pollution has been associated with COPD mortality, ${ }^{50}$ as have decrements in lung function among people with asthma. ${ }^{51,52}$

\section{Introduction to the pathophysiology of asthma and COPD Asthma pathophysiology}

Asthma is predominantly an airway disease, generally without involvement of lung parenchyma. It is viewed as a condition characterized by Type 2 helper T cell (Th2) cytokine-mediated eosinophilic airway inflammation. Bronchial biopsies from subjects with asthma demonstrate infiltration with eosinophils, activated mast cells, and Th2 predominant $T$ cells. ${ }^{53}$ There is also significant thickening due to collagen deposition in the basement membrane underpinning the bronchial epithelium. The concept of a variety of asthma syndromes is longstanding. ${ }^{2}$ However, recent studies have highlighted the potential for the presence of a variety of different pathological asthma phenotypes, with some studies 
demonstrating neutrophilic or paucigranulocytic findings in sputum rather than eosinophilia in patients with a range of asthma severities. $^{2}$

Asthma is associated with AHR, which may be evident though reversibility to BD on spirometric testing or through responses to a variety of challenge tests. Asthma symptoms classically relapse and remit over time and are responsive to corticosteroids. However, over time, a proportion of individuals with asthma may develop some degree of persistent airflow obstruction, which does not remit with antiinflammatory therapy. ${ }^{54}$ In this case, differentiation from COPD may be very difficult. As around $30 \%$ of people with asthma smoke, a proportion of these will develop chronic airflow limitation, which is likely to be indistinguishable from COPD. Recent studies suggest that $13 \%-20 \%$ of patients with COPD have an overlap phenotype with asthma; this is as high as $50 \%$ in patients over 50 years. ${ }^{54-57}$

\section{COPD pathophysiology}

In COPD, repeated exposure to noxious stimuli triggers an inflammatory response, which appears to continue even after removal of the inciting stimulus. ${ }^{58}$ Early inflammation in young smokers is associated with mononuclear cells in the airway wall and macrophages in the small airway lumen. In patients with established COPD, the inflammatory cell infiltrate in small airways comprises predominantly neutrophils, cluster of differentiation (CD)8 positive lymphocytes, and mast cells. ${ }^{59}$ There may be associated "spill-over" of the inflammatory response from the lungs into the systemic circulation, leading to potential downstream effects such as arterial stiffness and its consequences. ${ }^{60,61}$

Although, as with asthma, there has been a tendency to "lump" patients with COPD into a homogeneous group, clinicians have for decades recognized variations in clinical phenotype of patients with COPD, which is underpinned, to an extent, by variations in the underlying pathology. Pathological features of small airways disease may predominate, with such patients having relatively minimal parenchymal destruction. Other patients may have relative sparing of airways and a more prominent picture of acinar destruction (emphysema). Parenchymal destruction is associated with loss of lung tissue elasticity, and small airways collapse during exhalation, leading to so-called "gas trapping". Goblet cell metaplasia and impaired mucociliary function contribute to excess mucus accumulation and worsening obstruction.

An approach to grading and treating COPD based on clinical phenotypes aligned to pathology has been described in the recent Spanish COPD guidelines, which propose four different phenotypes including 1) infrequent exacerbators with either chronic bronchitis or emphysema, 2) asthmaCOPD overlap, 3) frequent exacerbators with emphysema predominant, and 4) frequent exacerbators with chronic bronchitis predominant. ${ }^{62}$ It has been proposed that such clinical phenotypes may help clinicians identify patients that respond to specific pharmacological interventions.

\section{The role of age in both diseases Age-related features}

Asthma of an earlier onset is closely linked to other allergic diseases and to skin test sensitivity. ${ }^{63}$ Most children with the persistent asthma phenotype have current symptoms as adults; however, around half are in remission by midadulthood. ${ }^{64}$ Compared to childhood-onset asthma, asthma of adult onset is more likely among nonatopic females and features a greater fall in lung function despite a shorter duration of disease. ${ }^{63,65} \mathrm{~A}$ history of allergic rhinitis, and less so, atopic dermatitis, were associated with retrospectively recalled history of physician-diagnosed asthma from age 16 years for young to middle-aged adults in the European Community Respiratory Health Survey. ${ }^{24}$ However, there was no association between skin test positivity and adult-onset asthma for middle-aged adults followed for 14 years in the Busselton Health Study. ${ }^{40}$

The diagnostic value of atopy in distinguishing adultonset asthma from COPD decreases with advancing age despite increasing levels of sensitization until mid-adult life, which plateau after the age of 55 years. ${ }^{66}$ The adult-onset asthma phenotype shares similar clinical features with the noneosinophilic asthma phenotype and like COPD is associated with greater corticosteroid resistance when compared with younger individuals with eosinophilic asthma. ${ }^{67}$

For those with childhood asthma who become asymptomatic by mid-adolescence, a recurrence of asthma symptoms in adulthood may be misclassified as "adult-onset asthma" if the past childhood history cannot be recalled. ${ }^{68,69}$ One epidemiological study that prospectively documented childhood asthma and/or wheezy breathing when participants were aged 7 years, identified two-thirds of young adults as being unable to accurately recall their childhood history, and this was mostly for those without severe eczema or allergic rhinitis. ${ }^{69}$

COPD generally manifests clinically from mid-adult life, with increasing prevalence and disease severity with advancing age. ${ }^{12}$ The rate of disease progression varies between individuals, with an accelerated $\mathrm{FEV}_{1}$ decline more common for current smokers and those with BD-reversibility, emphysema, and/or acute exacerbations. ${ }^{70}$ The link between 
advanced age and COPD may be weakening for populations of developed countries given that the probability of asthma as the cause for underlying symptoms for an older individual seems to have increased, particularly for countries of high asthma prevalence. This requires validation by prospective cohorts that use consistent asthma and COPD definitions over time.

Apart from respiratory infection, adults with asthma appeared to have less comorbidity than those with COPD. ${ }^{71}$ COPD is associated with multiple comorbidities including ischemic heart disease, cardiac failure, osteoporosis and muscle weakness, obesity and the metabolic syndrome, depression and anxiety, lung cancer, pneumonia, ${ }^{71}$ and pulmonary embolism. ${ }^{72}$ Although these may be due in part to the common risk factor of smoking, the development of the comorbidities may also be linked by systemic inflammation driven by the elevation of proinflammatory mediators and their receptors, including tumor necrosis factor alpha, interleukin (IL)-6, and IL-1 receptor antagonist IL-1Ra, leading to an increased production of diverse chemokines (RANTES, MIP-1 $\alpha$, IL-8, MCP-1) and an increase in C-reactive protein. ${ }^{61,73-75}$

\section{Altered perception of airway obstruction}

Some data have suggested that for people over 65 years, those with adult-onset asthma of a longer duration may have more severe airway obstruction than those with a more recent asthma diagnosis, yet they report fewer asthma symptoms. ${ }^{76}$ This might adversely influence the implementation of an asthma action plan, which relies on the accurate interpretation of asthma symptoms. ${ }^{77}$ Older individuals might attribute respiratory symptoms to bronchitis, respiratory tract infection, obesity, poor fitness, or even to the "aging process" $" 77$ and be more accepting of a progressive decline in mobility and activity. ${ }^{4}$

\section{Differential diagnosis of adult asthma and COPD}

Dyspnea due to cardiac failure is a common and important differential diagnosis for adult-onset asthma and COPD in the elderly, including acute exacerbations of COPD.$^{72}$ Bronchiectasis is another important differential diagnosis for nonsmoking individuals with post-BD airflow obstruction and a productive cough, particularly for females. Bronchiectasis can complicate severe asthma in the form of allergic bronchopulmonary aspergillosis, where identifying proximal bronchial dilatation on high resolution computed tomography
(HRCT) chest scan may be used to confirm the diagnosis. An accelerated $\mathrm{FEV}_{1}$ decline has been observed for those with clinically apparent bronchiectasis despite medical therapy, averaging $49 \mathrm{~mL}$ per year over an 8 year period. ${ }^{78}$ Around half of older COPD patients with moderate to severe airflow obstruction have been documented to have radiologicallydefined bronchiectasis when screened with HRCT chest scans. ${ }^{79,80}$ As bronchiectasis is frequently associated with $\mathrm{AHR}^{81}$ and/or BD-reversibility, it seems possible that this entity could contribute to the overlap between asthma and COPD. Bronchiectasis in the presence of COPD is also a poor prognostic marker, where its severity has been independently associated with increases in all-cause mortality. ${ }^{80}$

\section{Asthma}

Clinical practice guidelines propose diagnostic criteria to assist clinicians in distinguishing between asthma and other obstructive airway diseases. ${ }^{4} \mathrm{~A}$ diagnosis of asthma is made following a clinical assessment of symptoms and demonstration of variable airflow obstruction. This hallmark feature of asthma can be assessed by performing pre-BD and post-BD spirometry. ${ }^{4}$ An improvement of $\mathrm{FEV}_{1}$ and/or FVC of greater than $12 \%$ or $200 \mathrm{~mL}$ is considered a significant $\mathrm{BD}$ response, consistent with asthma. ${ }^{82}$ However, such BD responses may also be seen in patients with $\mathrm{COPD},{ }^{83}$ and a subgroup of patients with long standing asthma do not demonstrate reversible airflow obstruction, ${ }^{84}$ which creates diagnostic challenges for clinicians.

Another diagnostic measure used in the assessment of asthma is AHR, a term that describes the ability of the airways to narrow excessively after exposure to bronchoconstrictor agonists. ${ }^{85} \mathrm{AHR}$ plays a crucial role in the pathogenesis of asthma, ${ }^{85}$ and the severity of AHR predicts the response to inhaled corticosteroids. ${ }^{86}$ However, in an older population, AHR is a common and important determinant of accelerated decline in lung function. ${ }^{87}$ This makes AHR a risk factor for the progression of airflow limitation in COPD,${ }^{88}$ and while AHR is a common physiological component of asthma, it is also frequently present in patients with COPD.

\section{COPD}

As previously mentioned, there are disease-specific guidelines and recommendations that propose diagnostic criteria to assist clinicians in the diagnosis of COPD. ${ }^{89}$ The GOLD recommendations define a post-BD $\mathrm{FEV}_{1} / \mathrm{FVC}$ of less than 0.7 as diagnostic of COPD., ${ }^{5,21}$ These recommendations also define spirometric indexes for grading severity, 
and treatment recommendations are based on this severity grading scale..$^{5,21}$

A normal gas transfer factor in symptomatic smokers with airflow obstruction is an inexpensive and simple measurement to exclude significant morphological emphysema, whereas variable amounts of emphysema can be present for those with low gas transfer factor levels..$^{90}$ The use of HRCT can identify individuals with a predominant emphysematous phenotype, where the extent of low attenuation areas has been linked to increased respiratory mortality. ${ }^{91}$ These data suggest that the identification of COPD-associated emphysema and/or bronchiectasis has some prognostic value, although HRCT scans are not currently recommended in the routine clinical management of COPD. ${ }^{21}$

\section{Differentiating adult asthma and COPD}

In differentiating the two diseases a number of factors are often considered (Table 1), including

1. accurate medical history involving assessment of age of symptom onset and variability of symptoms;

2. reversibility of airflow obstruction and $\mathrm{BD}$ response;

3. smoking and occupational history;
4. response to treatment trials;

5. and atopic status.

Each of these, however, is associated with error due to the overlap and convergence of symptoms and clinical characteristics. We have outlined the traditional approach to differentiating asthma and COPD and the problems associated with this approach in Table 1.

Recently, airway inflammation has been frequently but erroneously considered in the differential diagnosis of asthma and COPD. While the assessment of airway inflammation can assist in the guidance of treatment decisions, it does not differentiate between diagnoses due to the heterogeneity of inflammation across and within disease groups.

The question that must be asked then is, does it matter? One argument is to justify alternative management approaches. However, treatments for asthma and COPD have tended to converge, and there is a large degree of overlap for treatment recommendations in these diseases. ${ }^{10}$ This is discussed further in the next section.

As a counter argument, COPD prognosis differs significantly from that of asthma, and this may also apply to asthma-COPD overlap. In a recent longitudinal study,

Table I Common symptoms, physiology, and pathology used to distinguish asthma and COPD and the common problems with this approach

\begin{tabular}{|c|c|c|}
\hline \multicolumn{2}{|c|}{ Traditional approach to differentiating disease } & \multirow[t]{2}{*}{ Problems with this approach } \\
\hline Asthma & COPD & \\
\hline $\begin{array}{l}\text { Onset anytime throughout } \\
\text { lifespan and often early in life } \\
\text { (childhood) }\end{array}$ & $\begin{array}{l}\text { Onset usually after the } \\
\text { age of } 40 \text { years }\end{array}$ & Asthma is frequently diagnosed in adults and older people. ${ }^{10}$ \\
\hline Often atopic & Usually not atopic & $\begin{array}{l}\text { Atopy also occurs in COPD }{ }^{92} \text { and not in all people with asthma, } \\
\text { particularly those with adult-onset disease. }{ }^{93}\end{array}$ \\
\hline $\begin{array}{l}\text { Symptoms often worse at night } \\
\text { and in the morning }\end{array}$ & Dyspnoeic with activity & $\begin{array}{l}\text { A subgroup of patients with long-standing asthma do not } \\
\text { demonstrate reversible airflow obstruction. AHR and }\end{array}$ \\
\hline Variable symptoms & $\begin{array}{l}\text { Progressive symptoms } \\
\text { over time }\end{array}$ & $\begin{array}{l}\text { bronchodilator responsiveness are common features of COPD } \\
\text { and asthma. }{ }^{94-96} \text { Symptoms may be specific to the patho- }\end{array}$ \\
\hline Reversible airflow obstruction & $\begin{array}{l}\text { Only partially reversible } \\
\text { airflow obstruction }\end{array}$ & $\begin{array}{l}\text { physiological component of the disease rather than aligning with } \\
\text { the diagnosis. }\end{array}$ \\
\hline $\begin{array}{l}\text { Airway inflammation - } \\
\text { eosinophilic predominant }\end{array}$ & $\begin{array}{l}\text { Airway inflammation } \\
\text { neutrophilic predominant }\end{array}$ & $\begin{array}{l}\text { The presence of inflammatory cells in the airways does not } \\
\text { diagnose asthma or COPD, but their measurement is useful } \\
\text { for clinical assessment and may guide treatment decisions. } \\
\text { Moreover, airway inflammation is heterogeneous, and these } \\
\text { inflammatory phenotypes do not define disease states. }{ }^{97,98}\end{array}$ \\
\hline $\begin{array}{l}\text { May or may not have a history } \\
\text { of smoking }\end{array}$ & $\begin{array}{l}>10 \text { pack year smoking } \\
\text { history }\end{array}$ & $\begin{array}{l}\text { Data suggests that a high proportion of COPD patients are } \\
\text { never smokers, }{ }^{99} \text { and smoking rates among patients with asthma } \\
\text { are high. }{ }^{100}\end{array}$ \\
\hline \multicolumn{2}{|c|}{3 month-course of inhaled corticosteroids } & $\begin{array}{l}\text { A moderate proportion of patients with COPD have eosinophilic } \\
\text { airway inflammation }{ }^{101} \text { and may have a therapeutic response } \\
\text { to corticosteroids. Conversely, patients with noneosinophilic } \\
\text { asthma }{ }^{102} \text { may be less likely to respond to corticosteroids. }\end{array}$ \\
\hline
\end{tabular}

Abbreviations: AHR, airway hyper-responsiveness; COPD, chronic obstructive pulmonary disease. 
Fu et al evaluated and compared clinical outcomes of patients with asthma, COPD, and asthma-COPD overlap at baseline and 4 years. ${ }^{103}$ The results showed significantly greater decline in 6 minute walk distance at 4 years in the COPD group compared with the asthma and the overlap groups. In another cross sectional study, patients with overlap of asthma and COPD had significantly poorer quality of life and were more likely to have experienced a severe exacerbation (odds ratio 3.55, 95\% confidence interval 1.76, 7.15) of their airways disease in the last year, than those with COPD alone. ${ }^{104}$

The differentiation of asthma and COPD is particularly difficult in older people, where the common pathophysiological components of airflow obstruction, AHR, and airway inflammation overlap and converge and where, in patients over the age of 55 years, overlap of asthma and COPD occurs in up to $50 \%$ of individuals. ${ }^{10,55,56}$
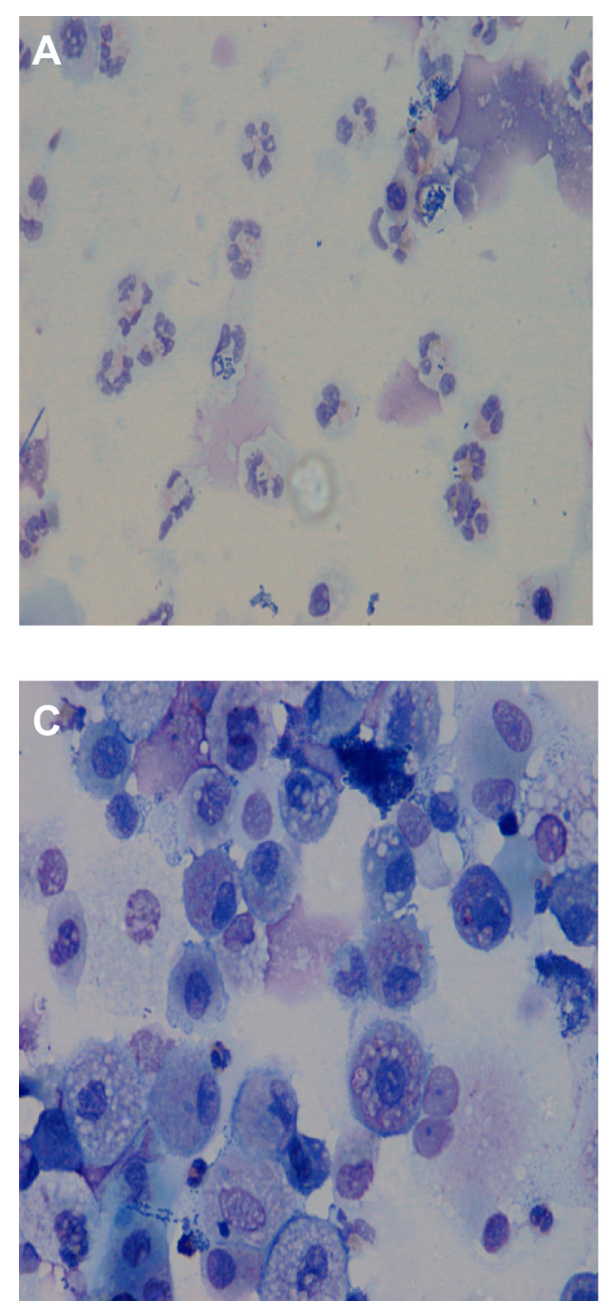

\section{New approaches using inflammometry}

In recognition of this difficulty with traditional approaches, alternative approaches to the assessment and management of obstructive airway diseases in adults have been proposed. ${ }^{9-11,97,105}$ These new approaches challenge the rigid categorization of patients into existing diagnostic labels of either asthma or COPD and suggest the importance of multiple clinical, functional, immunological, and molecular assessments that may be used to tailor and optimize treatments. ${ }^{9,105-108}$

Central to these approaches is inflammometry: the measurement of inflammation to guide treatment decisions. ${ }^{97}$ Importantly, in this management approach, the presence of inflammatory cells in the airways does not diagnose asthma or COPD, but their measurement can be useful for clinical assessment in guiding treatment decisions and in long-term
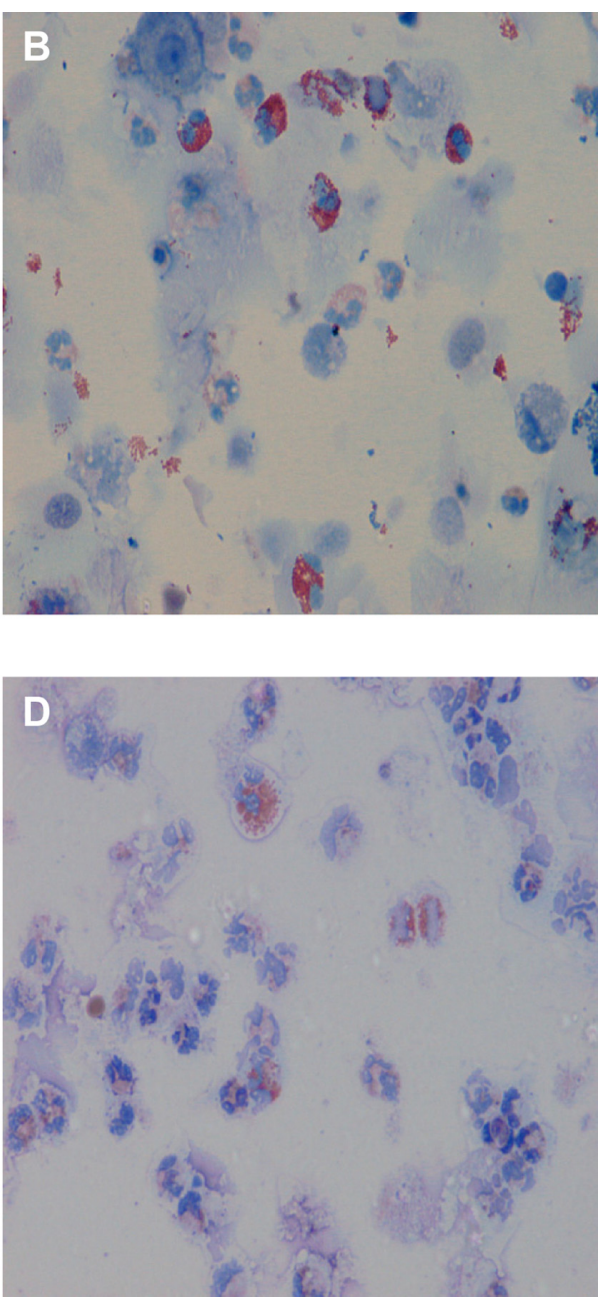

Figure I Airway inflammation phenotypes present in sputum from asthma and COPD patients.

Notes: (A) Neutrophilic airway inflammation. (B) Eosinophilic airway inflammation. (C) Paucigranulocytic airway inflammation. (D) Mixed neutrophilic/eosinophilic inflammation. 
monitoring. High quality evidence from many well-designed clinical trials ${ }^{109-111}$ and a systematic review ${ }^{112}$ report the superior effects of targeting airway eosinophilic inflammation on exacerbation reduction in both asthma and COPD. Airway inflammation in both asthma and COPD is heterogeneous, with four different airway inflammatory phenotypes having been described (Figure 1):

1. Eosinophilic

2. Neutrophilic

3. Paucigranulocytic

4. Mixed eosinophilic and neutrophilic.

Although traditionally asthma is considered an eosinophilic disease and COPD is associated with airway neutrophilia, the heterogeneity of sputum cellularity in these diseases is now increasingly recognized, with many studies reporting airway eosinophilia in COPD and airway neutrophilia in asthma. ${ }^{96,102,107,113,114}$

In a large cross sectional study of patients with airways disease, D'Silva et al reported the cellular profile of over 4,000 induced or spontaneous sputum samples. ${ }^{101}$ In the group with asthma-COPD overlap, eosinophilic bronchitis was seen in 35\%, neutrophilic bronchitis in 19\%, and a mixed inflammatory pattern in $10 \%$. In COPD, the phenotypes were respectively $18 \%, 34 \%$, and $7 \%$, and in asthma alone $26 \%$,
$14 \%$, and $6 \%$. These data demonstrate the heterogeneous nature of airway inflammation in asthma and COPD. The assessment of airway inflammation in airways disease may be important in order to tailor treatment more effectively.

Gonem et al proposed an approach that tailors treatment using a classification system that takes into account a number of pathophysiological components rather than disease labels. ${ }^{105}$ The A to E system includes assessment and management of $A$ HR, Bronchitis (airway inflammatory phenotype), Cough reflex sensitivity, Damage (relating to BD and corticosteroidresistant airflow obstruction resulting from airway and parenchymal damage), and Extra pulmonary factors. This system remains an important current research area.

Gibson et al, ${ }^{10}$ McDonald et al, ${ }^{11}$ and McDonald and Gibson $^{115}$ propose an approach targeted at older patients and those with difficult airways disease. They suggest a model of multidimensional assessment and individualized management focusing on the four domains: airways, comorbidity, self-management, and risk factors (Figure 2). In a pilot study comparing management using this approach to usual care, the intervention achieved significant improvements in health status as well as in both airway and systemic inflammation. This study suggested that a personalized approach was feasible and could result in superior outcomes, but larger studies are required. ${ }^{107}$

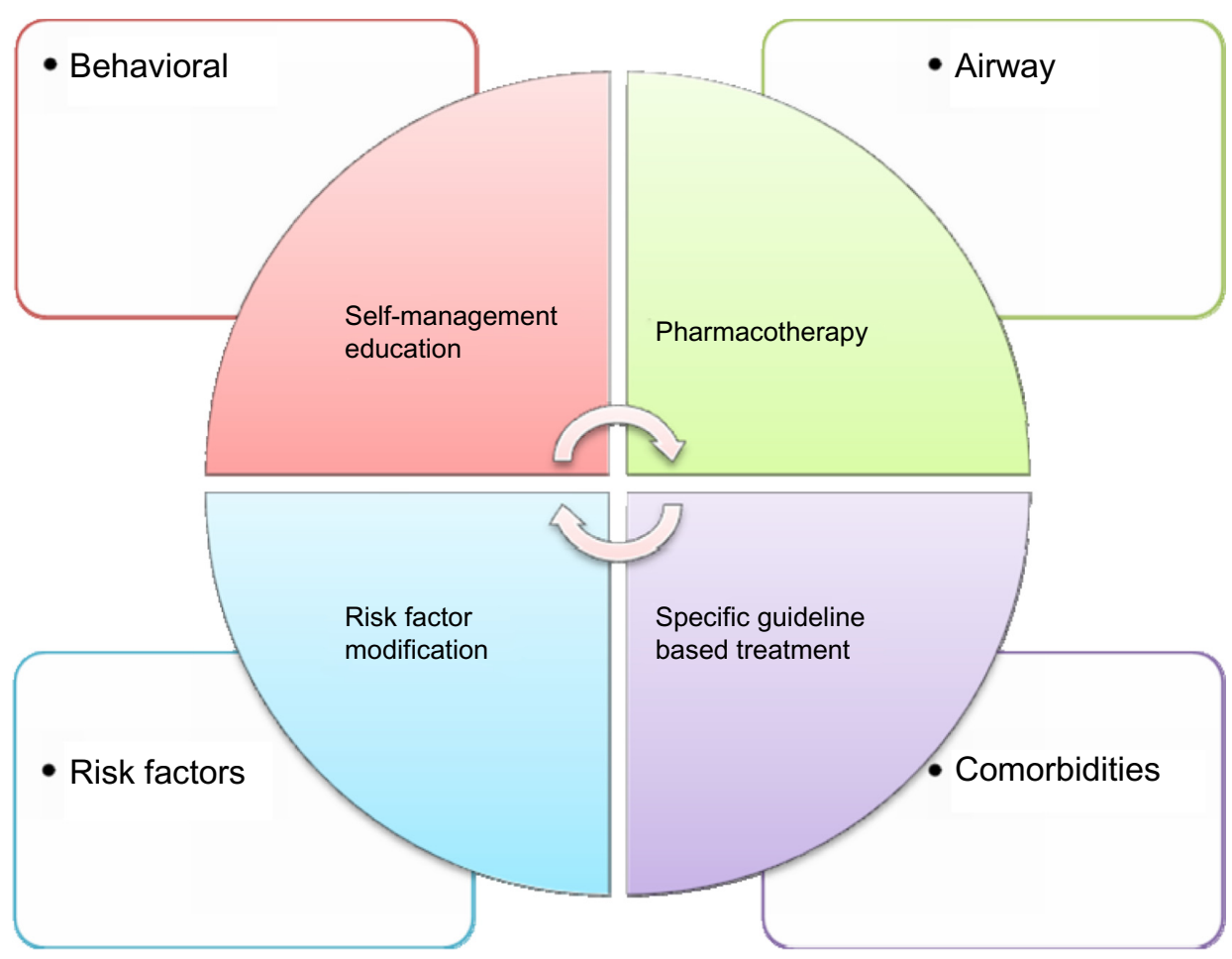

Figure 2 Model of disease components and individualized treatment approach. Note: Reprinted from The Lancet, 376, Gibson PG, McDonald VM, Marks GB, Asthma in older adults, 803-8I3, Copyright 20I0, with permission from Elsevier. ${ }^{10}$ 


\section{Differential management of adult asthma and COPD}

Guidance for clinicians around the world is provided by the Global Initiative for Asthma ${ }^{4}$ and GOLD. ${ }^{21}$ However, clinical practice guidelines need to be adapted to national and local conditions. ${ }^{89,116}$ The detailed management of acute exacerbations is beyond the scope of this review.

There are features common to the management of both adult-onset asthma and COPD. Both conditions require the development of a partnership between patients and their health care providers. Both conditions also require the identification and reduction of exposure to risk factors. ${ }^{4}$ A short-acting beta-agonist such as salbutamol or terbutaline provides effective symptom relief in both asthma and COPD and may be the only medication that is required in mild intermittent asthma.

Optimal inhaler technique involving accurate coordination of device actuation and inhalation are necessary for appropriate delivery of any inhaled drug. These require adequate cognitive function, manual dexterity, and strength of the intrinsic muscles of the hand. Elderly individuals can have poor device technique although competence can improve through the use of education as well as breathactuated devices ${ }^{117}$ or large volume spacers. ${ }^{118}$ Given that device selection can also be driven by convenience, cost, and patient preference, regular objective monitoring of inhaler technique and adherence is essential. ${ }^{17,119}$

Combination inhalers containing a long-acting betaagonist (LABA) and corticosteroid are widely used both in asthma and COPD. Preventer (or controller) medication is recommended for adults who report asthma symptoms twice or more during the past month, waking due to asthma symptoms once or more during the past month, or an asthma flare-up in the previous 12 months. ${ }^{116} \mathrm{~A}$ single fixed dose combination inhaler may enhance adherence to inhaled corticosteroids in asthma, ${ }^{120}$ and several randomized controlled trials suggest that single inhaler therapy reduces asthma exacerbations requiring oral corticosteroids, hospitalization, or emergency visits. ${ }^{121}$ The TOwards a Revolution in COPD Health (TORCH) trial found a modest reduction in mortality among COPD patients who were randomized to the combination of salmeterol and fluticasone compared to placebo. ${ }^{122}$ However, those who received the inhaled corticosteroid appeared to have an increased risk of pneumonia, although this was not radiologically confirmed. A meta-analysis of 24 randomized controlled trials suggested that the increased risk of pneumonia might be a class effect of inhaled corticosteroids. ${ }^{123}$
Systemic corticosteroids are generally recommended in patients with moderate or severe exacerbations of asthma. Oral corticosteroids are as effective as injected corticosteroids, provided they can be swallowed and retained. ${ }^{116}$ Prednisolone 40-50 mg daily (or parenteral hydrocortisone $400 \mathrm{mg}$ daily) is as effective as higher doses in hospitalized patients with severe exacerbations of asthma. ${ }^{124}$ Similarly, systemic corticosteroids reduce the risk of treatment failure and the need for additional treatment for an exacerbation of COPD, as well as shortening hospital stay. ${ }^{125} \mathrm{~A}$ short course of $40 \mathrm{mg}$ prednisone daily for 5 days was recently shown to have non-inferior outcomes to a 2-week course at the same dosage. ${ }^{126}$ Because of the risk of adverse effects, long-term use of oral corticosteroids is not recommended in either asthma or COPD. Specific complications include osteoporosis, weight gain, immobility, insomnia, emotional lability, glucose intolerance and diabetes mellitus, susceptibility to infection, skin atrophy, impaired wound healing, fluid retention, and increased cardiovascular risk. ${ }^{127}$

\section{Distinctive features of asthma management}

Written asthma action plans are a cornerstone of asthma management in adults. A systematic review found that optimal self-management allowing for optimization of asthma control by adjustment of medications may be conducted by either self-adjustment with the aid of a written action plan or by regular medical review. ${ }^{128}$ Having a written action plan was also associated with a reduced risk of death from asthma. ${ }^{129}$ Although widely recommended in guidelines, the evidence for self-management in COPD is less compelling. A systematic review of 29 randomized controlled trials of selfmanagement education (SME) compared to usual care found that SME in COPD led to a significant reduction in respiratory related hospital admission and improved health related quality of life and dyspnea. While the authors concluded that SME improves these outcomes, due to the heterogeneity of the interventions, study populations, follow-up time, and outcome measures data are still insufficient to formulate clear recommendations regarding the form and contents of SME programs in COPD. ${ }^{130}$ Another systematic review concluded that giving patients an action plan and limited SME for the management of COPD exacerbations could not be recommended as the standard of care..$^{131}$

\section{The stepwise approach}

The current management of asthma in adults is based on achieving asthma control and involves a stepwise approach, ${ }^{4}$ titrating 


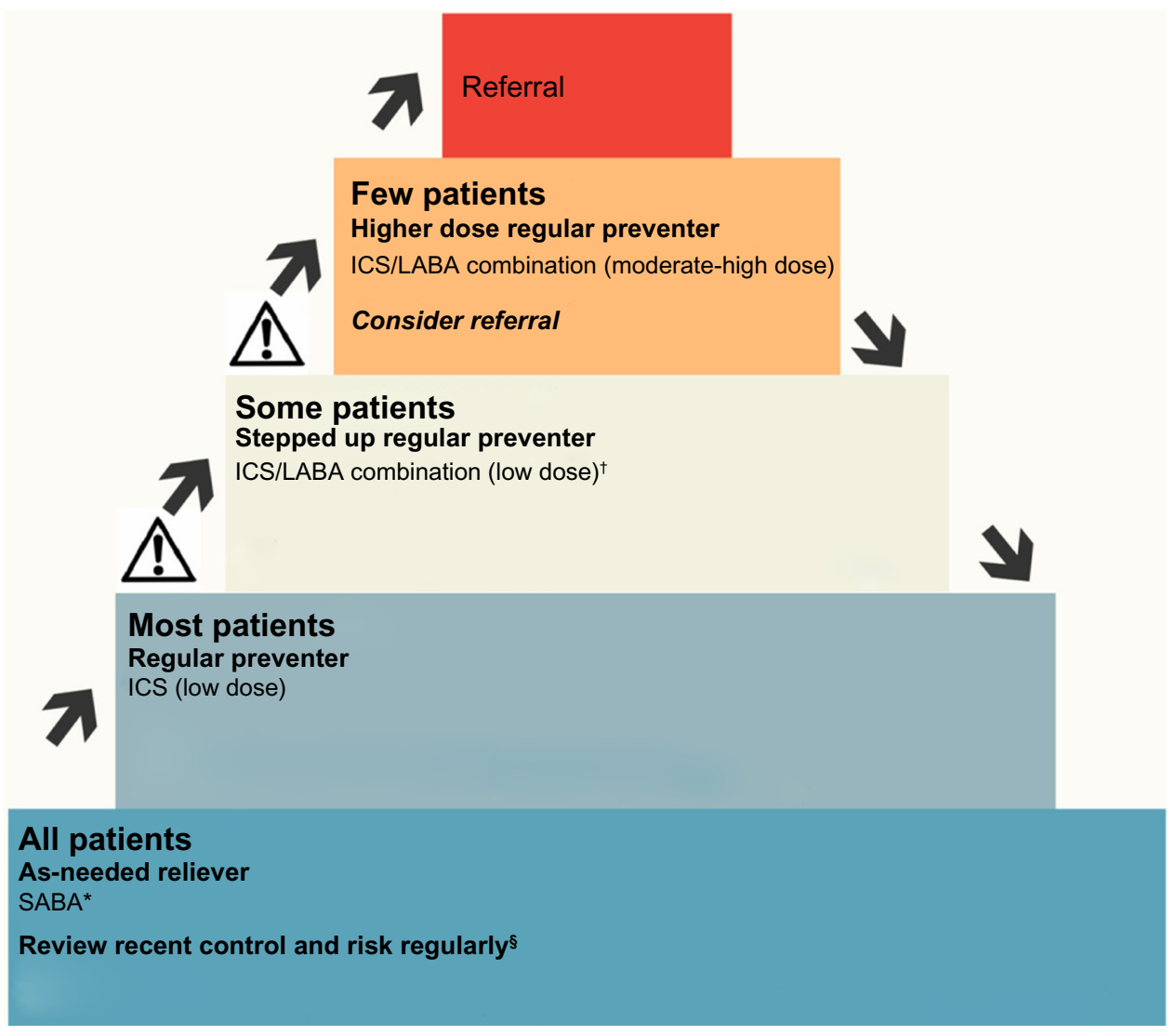

Figure 3 Stepped approach to adjusting asthma medication in adults.

Notes: Copyright (c) 2014 National Asthma Council Australia. Adapted from: Figure: Stepped approach to adjusting asthma medication in adults (Asset ID 3I); National Asthma Council Australia. Australian Asthma Handbook, Version I.0. National Asthma Council Australia, Melbourne, 20I4. Available from: http://www.asthmahandbook. org.au. ${ }^{116}$ t. Montelukast can be added to inhaled corticosteroid as an alternative to switching to ICS/LABA, but is less effective. *, Reliever: Short-acting beta2 agonist (or low-dose budesonide/eformoterol combination for patients using this combination as both maintenance and reliever). $\S$, in addition, manage flare-ups with extra treatment when they occur, and manage exercise-related asthma symptoms as indicated.

Abbreviations: ICS, inhaled corticosteroids; LABA, long-acting beta-agonist; SABA, short-acting beta-agonist.

the inhaled corticosteroid dose, and adding other medications such as LABA, leukotriene modifier, oral corticosteroid, and monoclonal antibody therapy as necessary. When control improves, the dose of inhaled corticosteroid can be reduced and/or other medications ceased (Figure 3). However, there are currently few published trials of back-titration in COPD, so once commenced, many patients with COPD typically remain on high doses of inhaled corticosteroids. Back-titration studies are difficult given the challenges of reconciling the numerous COPD phenotypes that reflect the marked heterogeneity of the disease. ${ }^{132,133}$ A systematic review of three adequate quality trials of back-titration in COPD found that patients who had medication withdrawn were 1.11 (95\% confidence interval $0.84,1.46)$ times more likely to have an exacerbation in the following year. ${ }^{134}$ The results of the Withdrawal of Inhaled Steroids During Optimised bronchodilator Management (WISDOM) Trial ${ }^{135}$ are awaited with interest.

Leukotriene receptor antagonists such as montelukast are an alternative oral preventer in mild to moderate asthma.
They probably only have a limited role in adult patients, particularly those with aspirin or exercise-induced asthma. ${ }^{136}$ A systematic review of 56 randomized controlled trials found that monotherapy with inhaled corticosteroids was superior to leukotriene antagonists in reducing the requirement for rescue systemic corticosteroids or hospital admission, especially in adult patients with moderate airflow obstruction. ${ }^{137}$

As asthma is primarily an allergic disease, even in adults, new biological agents are being trialed targeting key molecules in the inflammatory pathways. Omalizumab is a monoclonal antibody directed against immunoglobulin E. A recent systematic review of 25 randomized controlled trials found that compared to placebo, subcutaneous omalizumab reduced the risk of exacerbations and permitted many patients to reduce or withdraw from inhaled corticosteroids. ${ }^{138}$ Mepolizumab is another monoclonal antibody directed against the cytokine IL-5. There are clinical trials showing that mepolizumab reduces exacerbations and improves quality of life in patients with refractory eosinophilic asthma. ${ }^{139}$ However, the high cost 
of these biological agents means that they can only be considered for patients with difficult to control asthma managed in specialist facilities, where patient selection and management is based on targeted phenotypes. ${ }^{140}$

\section{Distinctive features of COPD management}

Stable COPD requires both nonpharmacological and pharmacological management. Figure 4 illustrates a stepwise approach to guide treatment decisions.

\section{Smoking cessation}

The major risk factor for COPD is active tobacco smoking, ${ }^{21}$ so particular emphasis needs to be given to smoking cessation and maintenance of abstinence. There are now a wide range of interventions including telephone counseling, ${ }^{141}$ nicotine replacement therapies, ${ }^{142}$ and newer pharmacological agents such as bupropion/nortriptyline ${ }^{143}$ and varenicline, ${ }^{144}$ which are effective particularly when combined with behavioral support. ${ }^{145}$ New methods of delivery such as pharmacist-led interventions are being trialed in hospitalized patients. ${ }^{146}$ Of course, smoking cessation is also important in asthma as continued smoking can lead to fixed airflow limitation in susceptible patients.

\section{Antimuscarinic agents}

Long-acting inhaled antimuscarinic medications such as tiotropium, aclidinium, and glycopyrronium are particularly useful in COPD. Randomized controlled trials have demonstrated improvements in dyspnea, lung function, and quality of life compared to placebo or LABA. ${ }^{147}$ Tiotropium is also associated with a reduction in and prolongation of time to exacerbations. ${ }^{148}$ However, there does not appear to be any reduction in the rate of decline in lung function. ${ }^{149}$ The benefits come with an increase in adverse effects such as dry mouth and urinary retention. ${ }^{150}$ Some evidence is now emerging regarding the benefit of tiotropium in asthma. ${ }^{151,152}$

\section{Pulmonary rehabilitation}

Pulmonary rehabilitation programs involve patient assessment, exercise training, education, nutritional intervention, and psychosocial support. Systematic reviews have shown that in patients with COPD, these programs reduce dyspnea, fatigue, anxiety and depression; improve exercise capacity,

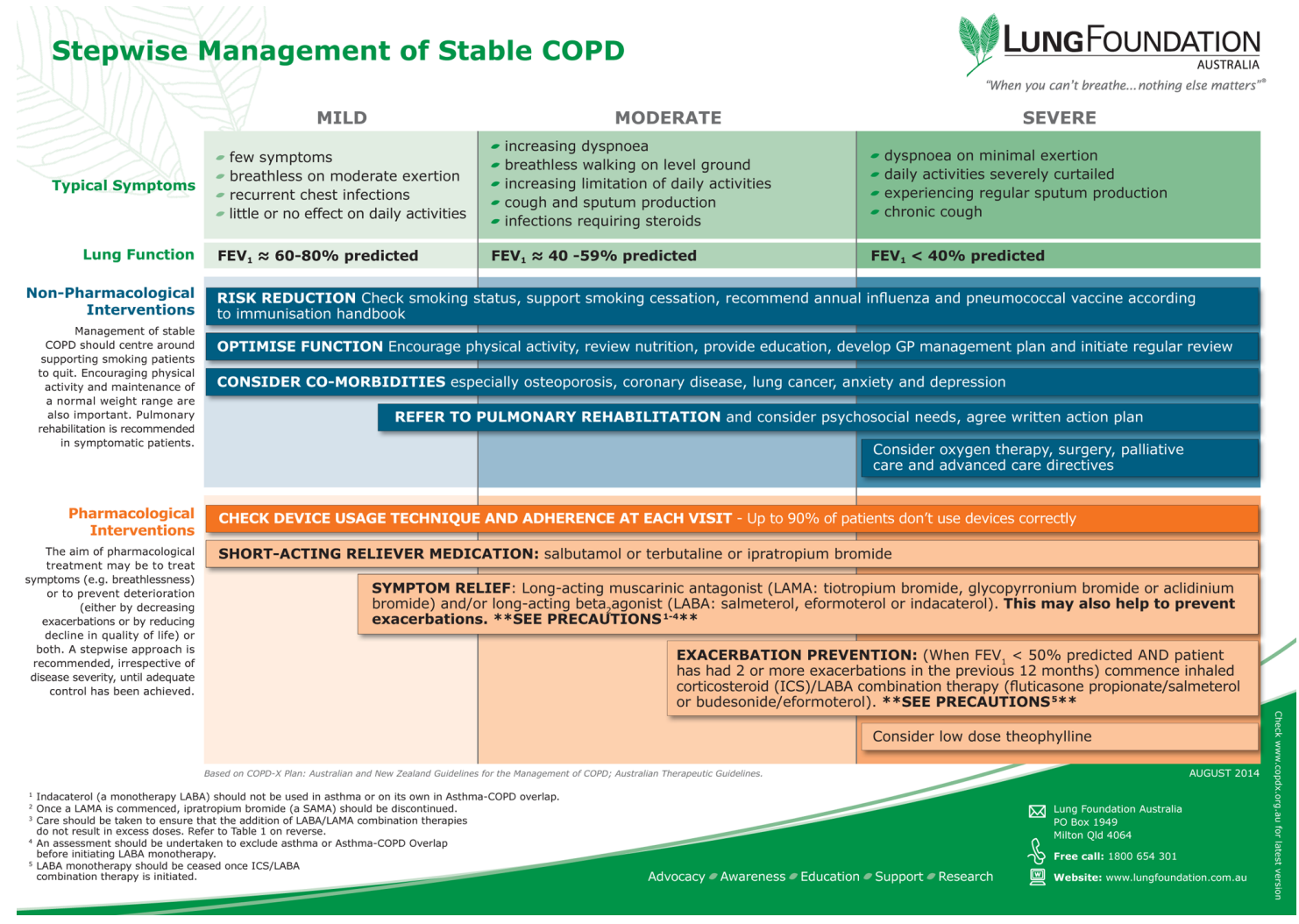

Figure 4 Stepwise management of Stable COPD.

Note: Copyright (C) 2012. Stepwise Management of Stable COPD. Reproduced with permission from the publisher, Lung Foundation Australia. Please visit www.copdx. org.au for the current version.

Abbreviations: COPD, chronic obstructive pulmonary disease; COPD-X, Confirm diagnosis, Optimise function, Prevent deterioration, Develop support, manage eXacerbations; FEV , forced expiratory volume in I second; GP, general practitioner; ICS, inhaled corticosteroids; LABA, long-acting beta-agonist. 
emotional function, and health-related quality of life; and enhance patients' sense of control over their condition. ${ }^{153}$ Pulmonary rehabilitation also reduces the length of hospitalization in COPD patients ${ }^{154}$ and is cost effective. ${ }^{155}$ In patients with asthma-COPD overlap, exercise training can improve symptoms and health status. ${ }^{156}$

Although access to comprehensive pulmonary rehabilitation varies with location, exercise training is an effective option in the management of patients with COPD if multidisciplinary education cannot be offered. ${ }^{157}$

\section{Action plans and self-management}

Action plans for exacerbations are effective in asthma, ${ }^{158}$ allowing patients to develop coping skills, anticipate early exacerbation symptoms, self-initiate appropriate treatment, and seek medical advice prior to significant deterioration. Trials assessing the effects of action plans in COPD management have shown conflicting results, with variable adjuncts to patient care likely contributors. Those with positive results, such as expedited exacerbation recovery and reduced hospital admissions, have included additional supports, such as intensive education and case management. ${ }^{159-161}$ In contrast, action plans with limited or no SME and no case management have little beneficial effect. ${ }^{131}$

A recent randomized controlled trial that suggested an unexpected increase in all-cause and COPD-specific mortality with a comprehensive care management program including a COPD action plan for US veterans, ${ }^{162}$ highlighted the value of identifying those with adult-onset asthma for whom the benefits are well-documented. Putting this disturbing finding into the context of the COPD literature is important, and identifying factors predisposing to a poor outcome will be a challenge for those involved in developing clinical practice guidelines. While the association did not appear related to increasing age or COPD severity, ${ }^{162}$ these findings suggest that self-management programs may not be appropriate for all patients with COPD.

\section{Home oxygen}

The use of domiciliary oxygen is common at the more severe end of the COPD spectrum. Indications to consider referral for assessment of need for long-term continuous oxygen therapy include severe airflow obstruction $\left(\mathrm{FEV}_{1}<30 \%\right.$ predicted), presence of cyanosis, polycythemia, signs of right heart failure, saturation of $\leq 92 \%$ breathing room air. ${ }^{163}$ Long-term continuous oxygen therapy has been proven to offer survival benefits and improved quality of life in patients with COPD and severe hypoxemia (arterial blood partial pressure of $\mathrm{O}_{2} \leq 55 \mathrm{mmHg}$ or $55-59 \mathrm{mmHg}$ with evidence of end-organ damage).

However, the role of oxygen therapy in patients with exertional desaturation, nocturnal hypoxemia, or resting mild-moderate hypoxemia is less clear. Recent studies suggest an absence of long-term effects on dyspnea or quality of life from the use of ambulatory oxygen therapy in normoxemic or mildly hypoxemic patients with COPD who desaturate with exertion, even though they may demonstrate small acute benefits during laboratory-based exercise tests. ${ }^{164,165}$ Occasional so-called "n-of-1 trials" may be of use in some individuals. ${ }^{165}$

Isolated nocturnal hypoxemia is not uncommon in COPD patients, particularly during rapid eye movement sleep. However, it has not been shown to lead to worse quality of life, daytime hypoxemia, or pulmonary hypertension. Limited studies have not consistently shown beneficial effects in sleep quality, pulmonary hemodynamics, or survival over 2 years with nocturnal supplemental oxygen. ${ }^{166-168}$ Similarly, patients with COPD and resting mild-moderate hypoxemia have not shown a survival benefit with domiciliary oxygen therapy. The currently recruiting US Long-term Oxygen Treatment Trial (NCT00692198) may provide more data regarding the effects of domiciliary oxygen in the latter patient subgroup.

\section{End of life care}

The disease trajectory for COPD is one of deteriorating health status and increasing morbidity, usually over a period of time. This differs from the more predictable trajectory of most cancers and as such, the most appropriate timing for discussions around end of life issues in COPD and referral time for palliative care are not clear. ${ }^{169}$ Despite this difficulty, primary care providers and specialist COPD teams have an integral role in developing partnerships with patients and carers to provide information about prognosis, and over time, should introduce topics regarding intubation, admission to intensive care unit, and patients' views on "not for resuscitation" or medical treatment orders. This involves a discussion regarding quality of life and choices they wish to consider. ${ }^{89} \mathrm{~A}$ useful resource to guide patients in making these choices is the Advance Care Planning website (http:// www.respectingpatientchoices.org.au). Opioids may have a role in patients with severe intractable dyspnea. ${ }^{170}$

Qualitative data suggest that there is a need for clinicians to improve their approach to end of life care in COPD. In one study, participants discussed their expectations about the future; this may have been fear about their future outcome or an idealistic expectation that they would not get any worse. 
These data suggest that participants did not have a clear understanding of their disease or of how it would progress. ${ }^{171}$ This is in accord with a study that interviewed 16 COPD patients within the last year of life. Even at this late stage, half of the participants expressed a desire for more information about their disease and its prognosis. ${ }^{172}$

\section{Areas for further research}

Although the importance and management of asthmaCOPD overlap remains a strongly debated topic, there are few data to inform practice and policy. This is because large scale randomized trials have largely excluded patients with asthma from COPD trials and those with COPD from asthma studies. ${ }^{173,177}$ Furthermore, epidemiological research to date has mainly treated these as two distinct groups of diseases and, therefore, not much evidence is available on the overlapping or distinctly separate groups. A number of clinical and epidemiological research questions remain outstanding.

An area that needs research is the current classifications for obstructive lung diseases. These classifications are complex, with asthma regarded as multiple overlapping syndromes, ${ }^{174}$ and the heterogeneity of both stable COPD and its acute exacerbations being increasingly recognized. ${ }^{133}$ The GOLD strategy document has progressively acknowledged the overlap between asthma and COPD, and progress is being made on a joint Global Initiative for Asthma/GOLD asthma-COPD overlap document. Other factors besides current or past smoking which may contribute to persistent airflow obstruction in asthma include severe symptoms, longstanding disease, old age at onset, frequent exacerbations, ongoing exposures to allergens and occupational irritants, aspirin sensitivity, elevated serum immunoglobulin E, and ongoing airway inflammation and hyperresponsiveness. ${ }^{175}$ With increasing recognition of this overlap phenotype, further revisions of the current taxonomy are likely to be developed. ${ }^{175}$ Given the limited data available for this subgroup, ${ }^{173,176}$ developing targeted management-specific guidelines poses challenges.

Clinical questions that need research include whether the unopposed use of LABA in asthma-COPD overlap is problematic, as it is in asthma without COPD. ${ }^{177}$ Likewise, does inhaled corticosteroid therapy in asthma-COPD overlap cause the same pneumonia risk as in COPD alone? Furthermore, back-titration of therapy is recommended in asthma as disease control improves. The approach to management involving back-titration in asthma-COPD overlap warrants further investigation. Finally, further clinical studies recruiting the population with asthma-COPD overlap and testing novel and personalized approaches are needed. The newly proposed system of the tailored treatment approach, which uses a classification system based on a number of pathophysiological components, remains an important current research area. ${ }^{105}$ A pilot study has shown that a personalized approach improved health status as well as both systemic and airway inflammation, but larger studies are required to confirm these findings. ${ }^{107}$

There has been increasing interest in understanding how long-standing asthma can lead to irreversible airflow limitation. ${ }^{34,49,65,84}$ In this context, distinguishing between adult-onset asthma and COPD can be especially difficult for the high proportion of adults with asthma who have smoked. It has been suggested that risk factors for the multiple phenotypes related to overlaps between asthma and $\mathrm{COPD}^{57}$ could vary. ${ }^{7}$ Understanding risk factors for these multiple phenotypes is critical to advancing knowledge of causal mechanisms and modifiable risk factors for both conditions.

\section{Conclusion}

Current clinical practice is based upon distinguishing between adult-onset asthma and COPD. There are separate guidelines for each condition. However, it is not always possible to clearly differentiate between these obstructive lung diseases because of common risk factors, such as tobacco smoking, and the convergence of symptoms and other clinical features. Studies based on newer approaches, for example, inflammometry, may result in better clinical outcomes. Further randomized controlled trials of these and other novel approaches, for example, a multidimensional approach targeting individualized management, should provide important data to inform future guidelines. The management of asthma and COPD is increasingly converging. This has already occurred for pharmacological therapies such as combination inhalers. Written action plans and self-management currently seem to be more useful in asthma than COPD. Further research is needed to examine back-titration of inhaled corticosteroids in COPD and to determine the best management of the common asthma-COPD overlap syndrome.

\section{Disclosure}

The authors report no conflicts of interest in this work.

\section{References}

1. Burgess JA, Matheson MC, Gurrin LC, et al. Factors influencing asthma remission: a longitudinal study from childhood to middle age. Thorax. 2011;66(6):508-513

2. Pavord ID. Non-eosinophilic asthma and the innate immune response. Thorax. 2007;62(3):193-194. 
3. Svanes C, Sunyer J, Plana E, et al. Early life origins of chronic obstructive pulmonary disease. Thorax. 2010;65(1):14-20.

4. Global Initiative for Asthma [homepage on the Internet]. Global Strategy for Asthma Management and Prevention; 2011. Available from: http:// www.ginasthma.org/GINA-Report,-Global-Strategy-for-AsthmaManagement-and-Prevention. Accessed March 21, 2014.

5. Pauwels RA, Buist AS, Calverley PM, Jenkins CR, Hurd SS; GOLD Scientific Committee. Global strategy for the diagnosis, management, and prevention of chronic obstructive pulmonary disease. NHLBI/ WHO Global Initiative for Chronic Obstructive Lung Disease (GOLD) Workshop summary. Am J Respir Crit Care Med. 2001;163(5): 1256-1276.

6. Rabe KF, Hurd S, Anzueto A, et al; Global Initiative for Chronic Obstructive Lung Disease. Global strategy for the diagnosis, management, and prevention of chronic obstructive pulmonary disease: GOLD executive summary. Am J Respir Crit Care Med. 2007;176(6):532-555.

7. Marsh SE, Travers J, Weatherall M, et al. Proportional classifications of COPD phenotypes. Thorax. 2008;63(9):761-767.

8. Gibson PG, Simpson JL. The overlap syndrome of asthma and COPD: what are its features and how important is it? Thorax. 2009;64(8): 728-735.

9. Guerra S. Asthma and chronic obstructive pulmonary disease. Curr Opin Allergy Clin Immunol. 2009;9(5):409-416.

10. Gibson PG, McDonald VM, Marks GB. Asthma in the older adults. Lancet. 2010;374(9743):803-813.

11. McDonald VM, Higgins I, Gibson PG. Managing older patients with coexistent asthma and chronic obstructive pulmonary disease: diagnostic and therapeutic challenges. Drugs Aging. 2013;30(1): 1-17.

12. Buist AS, McBurnie MA, Vollmer WM, et al; BOLD Collaborative Research Group. International variation in the prevalence of COPD (the BOLD Study): a population-based prevalence study. Lancet. 2007;370(9589):741-750.

13. Masoli M, Fabian D, Holt S, Beasley R; Global Initiative for Asthma (GINA) Program. The global burden of asthma: executive summary of the GINA Dissemination Committee report. Allergy. 2004;59(5): 469-478.

14. de Nijs SB, Venekamp LN, Bel EH. Adult-onset asthma: is it really different? Eur Respir Rev. 2013;22(127):44-52.

15. National Heart Lung and Blood Institute [homepage on the Internet]. Morbidity and Mortality: 2012 Chart Book on Cardiovascular, Lung and Blood Diseases; 2012 [updated 2013]. Washington, DC: National Institutes of Health, US Department of Health and Human Services. Available from: http://www.nhlbi.nih.gov/resources/docs/cht-book.htm. Accessed March 21, 2014.

16. McDonaldVM, Gibson PG. Asthma mortality and management in older Australians: time for a new approach? Australas J Ageing. 2008;27(4):215.

17. Australian Centre for Asthma Monitoring. Asthma in Australia 2011: with a focus chapter on chronic obstructive pulmonary disease [webpage on the Internet]. Canberra: Australian Institute of Health and Welfare; 2011. Available from: http://www.aihw.gov.au/publicationdetail/?id=10737420159. Accessed May 9, 2014.

18. Burney P, Chinn S, Jarvis D, Luczynska C, Lai E, on behalf of the European Community Respiratory Health Survey. Variations in the prevalence of respiratory symptoms, self-reported asthma attacks, and use of asthma medication in the European Community Respiratory Health Survey (ECRHS). Eur Respir J. 1996;9(4):687-695.

19. Lopez AD, Mathers CD, Ezzati M, Jamison DT, Murray CJ. Global and regional burden of disease and risk factors, 2001: systematic analysis of population health data. Lancet. 2006;367(9524):1747-1757.

20. Rycroft CE, Heyes A, Lanza L, Becker K. Epidemiology of chronic obstructive pulmonary disease: a literature review. Int J Chron Obstruct Pulmon Dis. 2012;7:457-494.

21. Global strategy for the diagnosis, management, and prevention of COPD [webpage on the Internet]. Global Initiative for Chronic Obstructive Lung Disease; 2014. Available from: http://www.goldcopd.org/ guidelines-global-strategy-for-diagnosis-management.html. Accessed March 21, 2014.
22. PunekarYS, Shukla A, Müllerova H. COPD management costs according to the frequency of COPD exacerbations in UK primary care. Int $J$ Chron Obstruct Pulmon Dis. 2014;9:65-73.

23. Cisternas MG, Blanc PD, Yen IH, et al. A comprehensive study of the direct and indirect costs of adult asthma. J Allergy Clin Immunol. 2003;111(6):1212-1218.

24. Torén K, Hermansson BA. Incidence rate of adult-onset asthma in relation to age, sex, atopy and smoking: a Swedish population-based study of 15813 adults. Int J Tuberc Lung Dis. 1999;3(3):192-197.

25. Toelle BG, Peat JK, Salome CM, Mellis CM, Woolcock AJ. Toward a definition of asthma for epidemiology. Am Rev Respir Dis. 1992;146(3):633-637.

26. Zhang X, Morrison-Carpenter T, Holt JB, Callahan DB. Trends in adult current asthma prevalence and contributing risk factors in the United States by state: 2000-2009. BMC Public Health. 2013;13:1156.

27. Pearce N, Ait-Khaled N, Beasley R, et al; ISAAC Phase Three Study Group. Worldwide trends in the prevalence of asthma symptoms: phase III of the International Study of Asthma and Allergies in Childhood (ISAAC). Thorax. 2007;62(9):758-766.

28. McHugh MK, Symanski E, Pompeii LA, Delclos GL. Prevalence of asthma among adult females and males in the United States: results from the National Health and Nutrition Examination Survey (NHANES), 2001-2004. J Asthma. 2009;46(8):759-766.

29. Toelle BG, Xuan W, Bird TE, et al. Respiratory symptoms and illness in older Australians: the Burden of Obstructive Lung Disease (BOLD) study. Med J Aust. 2013;198(3):144-148.

30. Molloy K, Hersh CP, Morris VB, et al. Clarification of the risk of chronic obstructive pulmonary disease in $\alpha 1$-antitrypsin deficiency PiMZ heterozygotes. Am J Respir Crit Care Med. 2014;189(4):419-427.

31. Hnizdo E, Glindmeyer HW, Petsonk EL, Enright P, Buist AS. Case definitions for chronic obstructive pulmonary disease. COPD. 2006;3(2):95-100.

32. Quanjer PH, Pretto JJ, Brazzale DJ, Boros PW. Grading the severity of airways obstruction: new wine in new bottles. Eur Respir J. 2014;43(2): 505-512.

33. Mehta A, Thun GA, Imboden M, et al. SERPINA1 PiMZ genotype, environmental and occupational exposure, and change in lung function. Paper presented at: ISEE Environment and Health; August 19-23, 2013; Basel, Switzerland.

34. Stern DA, Morgan WJ, Halonen M, Wright AL, Martinez FD. Wheezing and bronchial hyper-responsiveness in early childhood as predictors of newly diagnosed asthma in early adulthood: a longitudinal birth-cohort study. Lancet. 2008;372(9643):1058-1064.

35. Stocks J, Hislop A, Sonnappa S. Early lung development: lifelong effect on respiratory health and disease. Lancet Respir Med. 2013;1(9): $728-742$.

36. Gauderman WJ, Vora H, McConnell R, et al. Effect of exposure to traffic on lung development from 10 to 18 years of age: a cohort study. Lancet. 2007;369(9561):571-577.

37. Landau LI. Tobacco smoke exposure and tracking of lung function into adult life. Paediatr Respir Rev. 2008;9(1):39-43; quiz 43.

38. Gauderman WJ, Avol E, Gilliland F, et al. The effect of air pollution on lung development from 10 to 18 years of age. $N$ Engl $J$ Med. 2004;351(11):1057-1067.

39. Gilliland FD, Berhane K, Li YF, Rappaport EB, Peters JM. Effects of early onset asthma and in utero exposure to maternal smoking on childhood lung function. Am J Respir Crit Care Med. 2003;167(6): 917-924.

40. Jamrozik E, Knuiman MW, James A, Divitini M, Musk AW. Risk factors for adult-onset asthma: a 14-year longitudinal study. Respirology. 2009;14(6):814-821.

41. Hoy RF, Burgess JA, Benke G, et al. Occupational exposures and the development of new-onset asthma: a population-based cohort study from the ages of 13 to 44 years. J Occup Environ Med. 2013;55(3): 235-239.

42. Blanc PD, Iribarren C, Trupin L, et al. Occupational exposures and the risk of COPD: dusty trades revisited. Thorax. 2009;64(1):6-12. 
43. Svanes C. What has the ECRHS told us about the childhood risks of asthma, allergy and lung function? Clin Respir J. 2008; 2(Suppl 1):34-44.

44. Jenkins MA, Dharmage SC, Flander LB, et al. Parity and decreased use of oral contraceptives as predictors of asthma in young women. Clin Exp Allergy. 2006;36(5):609-613.

45. Real FG, Svanes C, Omenaas ER, et al. Lung function, respiratory symptoms, and the menopausal transition. J Allergy Clin Immunol. 2008;121(1):72-80. e3.

46. Romieu I, Fabre A, Fournier A, et al. Postmenopausal hormone therapy and asthma onset in the E3N cohort. Thorax. 2010;65(4): 292-297.

47. Po JY, FitzGerald JM, Carlsten C. Respiratory disease associated with solid biomass fuel exposure in rural women and children: systematic review and meta-analysis. Thorax. 2011;66(3):232-239.

48. Kurmi OP, Semple S, Simkhada P, Smith WC, Ayres JG. COPD and chronic bronchitis risk of indoor air pollution from solid fuel: a systematic review and meta-analysis. Thorax. 2010;65(3): 221-228.

49. Eisner MD, Anthonisen N, Coultas D, et al; Committee on Nonsmoking COPD, Environmental and Occupational Health Assembly. An official American Thoracic Society public policy statement: Novel risk factors and the global burden of chronic obstructive pulmonary disease. Am J Respir Crit Care Med. 2010;182(5):693-718.

50. Dimakopoulou K, Samoli E, Beelen R, et al. Air pollution and nonmalignant respiratory mortality in 16 cohorts within the ESCAPE project. Am J Respir Crit Care Med. 2014;189(6):684-696.

51. McCreanor J, Cullinan P, Nieuwenhuijsen MJ, et al. Respiratory effects of exposure to diesel traffic in persons with asthma. $N$ Engl J Med. 2007;357(23):2348-2358.

52. Balmes JR, Earnest G, Katz PP, et al. Exposure to traffic: lung function and health status in adults with asthma. J Allergy Clin Immunol. 2009;123(3):626-631.

53. Barnes PJ. The cytokine network in asthma and chronic obstructive pulmonary disease. J Clin Invest. 2008;118(11):3546-3556.

54. Broekema M, Timens W, Vonk JM, et al. Persisting remodeling and less airway wall eosinophil activation in complete remission of asthma. Am J Respir Crit Care Med. 2011;183(3):310-316.

55. Soriano JB, Davis KJ, Coleman B, Visick G, Mannino D, Pride NB The proportional Venn diagram of obstructive lung disease: two approximations from the United States and the United Kingdom. Chest. 2003;124(2):474-481.

56. Weatherall M, Travers J, Shirtcliffe PM, et al. Distinct clinical phenotypes of airways disease defined by cluster analysis. Eur Respir J. 2009;34(4):812-818.

57. Piras B, Miravitlles M. The overlap phenotype: the (missing) link between asthma and COPD. Multidiscip Respir Med. 2012;7(1):8.

58. Rutgers SR, Postma DS, ten Hacken NH, et al. Ongoing airway inflammation in patients with COPD who do not currently smoke. Thorax. 2000;55(1):12-18

59. Barnes PJ. Immunology of asthma and chronic obstructive pulmonary disease. Nat Rev Immunol. 2008;8(3):183-192.

60. Barnes PJ, Celli BR. Systemic manifestations and comorbidities of COPD. Eur Respir J. 2009;33(5):1165-1185.

61. Sinden NJ, Stockley RA. Systemic inflammation and comorbidity in COPD: a result of 'overspill' of inflammatory mediators from the lungs? Review of the evidence. Thorax. 2010;65(10):930-936.

62. Miravitlles M, Soler-Cataluña JJ, Calle M, et al. A new approach to grading and treating COPD based on clinical phenotypes: summary of the Spanish COPD guidelines (GesEPOC). Prim Care Respir J. 2013;22(1):117-121.

63. Miranda C, Busacker A, Balzar S, Trudeau J, Wenzel SE. Distinguishing severe asthma phenotypes: role of age at onset and eosinophilic inflammation. J Allergy Clin Immunol. 2004;113(1):101-108.

64. Tai A, Tran H, Roberts M, et al. Outcomes of childhood asthma to the age of 50 years. J Allergy Clin Immunol. 2014;133(6): 1572-1578. e3.
65. Perret JL, Dharmage SC, Matheson MC, et al. The interplay between the effects of lifetime asthma, smoking, and atopy on fixed airflow obstruction in middle age. Am J Respir Crit Care Med. 2013;187(1): 42-48

66. James AL, Knuiman MW, Divitini ML, et al. Changes in the prevalence of asthma in adults since 1966: the Busselton health study. Eur Respir J. 2010;35(2):273-278.

67. Haldar P, Pavord ID. Noneosinophilic asthma: a distinct clinical and pathologic phenotype. JAllergy Clin Immunol. 2007;119(5):1043-1052; quiz 1053.

68. Phelan PD. The natural history of asthma from childhood to adult life. In: Walls RS, Jenkins CR, editors. Understanding Asthma. A Management Companion. Eastgardens, NSW: MacLennan and Petty; 2000:20-25.

69. Burgess JA, Walters EH, Byrnes GB, et al. Who remembers whether they had asthma as children? J Asthma. 2006;43(10):727-730.

70. Vestbo J, Edwards LD, Scanlon PD, et al; ECLIPSE Investigators. Changes in forced expiratory volume in 1 second over time in COPD. N Engl J Med. 2011;365(13):1184-1192.

71. Soriano JB, Visick GT, Muellerova H, Payvandi N, Hansell AL. Patterns of comorbidities in newly diagnosed COPD and asthma in primary care. Chest. 2005;128(4):2099-2107.

72. Zvezdin B, Milutinov S, Kojicic M, et al. A postmortem analysis of major causes of early death in patients hospitalized with COPD exacerbation. Chest. 2009;136(2):376-380.

73. Arnson Y, Shoenfeld Y, Amital H. Effects of tobacco smoke on immunity, inflammation and autoimmunity. J Autoimmun. 2010;34(3):J258-J265.

74. Shaaban R, Kony S, Driss F, et al. Change in C-reactive protein levels and FEV1 decline: a longitudinal population-based study. Respir Med. 2006;100(12):2112-2120.

75. Sin DD, Man SF. Why are patients with chronic obstructive pulmonary disease at increased risk of cardiovascular diseases? The potential role of systemic inflammation in chronic obstructive pulmonary disease. Circulation. 2003;107(11):1514-1519.

76. Weiner P, Magadle R, Waizman J, Weiner M, Rabner M, Zamir D. Characteristics of asthma in the elderly. Eur Respir J. 1998;12(3): 564-568.

77. Goeman DP, Douglass JA. Understanding asthma in older Australians: a qualitative approach. Med J Aust. 2005;183(Suppl 1):S26-S27.

78. King PT, Holdsworth SR, Freezer NJ, Villanueva E, Gallagher M, Holmes PW. Outcome in adult bronchiectasis. COPD. 2005;2(1):27-34.

79. Patel IS, Vlahos I, Wilkinson TM, et al. Bronchiectasis, exacerbation indices, and inflammation in chronic obstructive pulmonary disease. Am J Respir Crit Care Med. 2004;170(4):400-407.

80. Martínez-García MA, de la Rosa Carrillo D, Soler-Cataluña JJ, et al. Prognostic value of bronchiectasis in patients with moderate-to-severe chronic obstructive pulmonary disease. Am J Respir Crit Care Med. 2013;187(8):823-831.

81. Pang J, Chan HS, Sung JY. Prevalence of asthma, atopy, and bronchial hyperreactivity in bronchiectasis: a controlled study. Thorax. 1989;44(11):948-951.

82. Pellegrino R, Viegi G, Brusasco V, et al. Interpretative strategies for lung function tests. Eur Respir J. 2005;26(5):948-968.

83. Tashkin DP, Celli B, Decramer M, et al. Bronchodilator responsiveness in patients with COPD. Eur Respir J. 2008;31(4):742-750.

84. Vonk JM, Jongepier H, Panhuysen CI, Schouten JP, Bleecker ER, Postma DS. Risk factors associated with the presence of irreversible airflow limitation and reduced transfer coefficient in patients with asthma after 26 years of follow up. Thorax. 2003;58(4):322-327.

85. O’Byrne PM, Inman MD. Airway hyperresponsiveness. Chest. 2003;123 (Suppl 3):411S-416S

86. Juniper EF, Frith PA, Hargreave FE. Airway responsiveness to histamine and methacholine: relationship to minimum treatment to control symptoms of asthma. Thorax. 1981;36(8):575-579.

87. Scichilone N, Messina M, Battaglia S, Catalano F, Bellia V. Airway hyperresponsiveness in the elderly: prevalence and clinical implications. Eur Respir J. 2005;25(2):364-375. 
88. Tashkin DP, Altose MD, Connett JE, Kanner RE, Lee WW, Wise RA. Methacholine reactivity predicts changes in lung function over time in smokers with early chronic obstructive pulmonary disease. The Lung Health Study Research Group. Am J Respir Crit Care Med. 1996; 153(6 Pt 1):1802-1811.

89. The COPD-X Plan. Australian and New Zealand Guidelines for the management of Chronic Obstructive Pulmonary Disease 2013 [webpage on the Internet]. Lung Foundation Australia; 2013. Available from: http://www.copdx.org.au/. Accessed July 25, 2014.

90. Cumming $\mathrm{G}$ and Hunt LB, ed. Form and function in the human lung: Proceedings of a Symposium held in the University of Birmingham, Birmingham, UK, 5-7 April 1967. Edinburgh, Scotland: E \& S Livingstone Ltd; 1968.

91. Johannessen A, Skorge TD, Bottai M, et al. Mortality by level of emphysema and airway wall thickness. Am J Respir Crit Care Med. 2013;187(6):602-608.

92. Fattahi F, ten Hacken NH, Löfdahl CG, et al. Atopy is a risk factor for respiratory symptoms in COPD patients: results from the EUROSCOP study. Respir Res. 2013;14:10.

93. Shaaban R, Zureik M, Soussan D, et al. Rhinitis and onset of asthma: a longitudinal population-based study. Lancet. 2008;372(9643):1049-1057.

94. Calverley PM, Burge PS, Spencer S, Anderson JA, Jones PW. Bronchodilator reversibility testing in chronic obstructive pulmonary disease. Thorax. 2003;58(8):659-664.

95. Reid DW, Soltani A, Johns DP, et al. Bronchodilator reversibility in Australian adults with chronic obstructive pulmonary disease. Intern Med J. 2003;33(12):572-577.

96. McDonald VM, Simpson JL, Higgins I, Gibson PG. Multidimensional assessment of older people with asthma and COPD: clinical management and health status. Age Ageing. 2011;40(1):42-49.

97. Pavord ID, Gibson PG. Inflammometry: the current state of play. Thorax. 2012;67(3):191-192.

98. Nair P. Update on clinical inflammometry for the management of airway diseases. Can Respir J. 2013;20(2):117-120.

99. Salvi SS, Barnes PJ. Chronic obstructive pulmonary disease in non-smokers. Lancet. 2009;374(9691):733-743.

100. Vozoris NT, Stanbrook MB. Smoking prevalence, behaviours, and cessation among individuals with COPD or asthma. Respir Med. 2011;105(3):477-484.

101. D'Silva L, Hassan N, Wang HY, et al. Heterogeneity of bronchitis in airway diseases in tertiary care clinical practice. Can Respir J. 2011;18(3):144-148.

102. Simpson JL, Scott R, Boyle MJ, Gibson PG. Inflammatory subtypes in asthma: assessment and identification using induced sputum. Respirology. 2006;11(1):54-61.

103. Fu JJ, Gibson PG, Simpson JL, McDonald VM. Longitudinal changes in clinical outcomes in older patients with asthma, COPD and asthmaCOPD overlap syndrome. Respiration. 2014;87(1):63-74.

104. Hardin M, Silverman EK, Barr RG, et al; COPDGene Investigators. The clinical features of the overlap between COPD and asthma. Respir Res. 2011;12:127.

105. Gonem S, Raj V, Wardlaw AJ, Pavord ID, Green R, Siddiqui S. Phenotyping airways disease: an A to E approach. Clin Exp Allergy. 2012;42(12):1664-1683.

106. Baines KJ, Simpson JL, Wood LG, Scott RJ, Gibson PG. Induced sputum differential gene expression implicates increased $\mathrm{p} 38$ signalling activity in severe asthma. Paper presented at: Annual Meeting of the European Respiratory Society Congress; September 24-28, 2011; Amsterdam, Netherlands.

107. McDonald VM, Higgins I, Wood LG, Gibson PG. Multidimensional assessment and tailored interventions for COPD: respiratory utopia or common sense? Thorax. 2013;68(7):691-694.

108. Pavord ID. Complex airway disease: an approach to assessment and management. Lancet Respir Med. 2013;1(1):84-90.

109. Green RH, Brightling CE, McKenna S, et al. Asthma exacerbations and sputum eosinophil counts: a randomised controlled trial. Lancet. 2002;360(9347):1715-1721.
110. Jayaram L, Pizzichini MM, Cook RJ, et al. Determining asthma treatment by monitoring sputum cell counts: effect on exacerbations. Eur Respir J. 2006;27(3):483-494.

111. Siva R, Green RH, Brightling CE, et al. Eosinophilic airway inflammation and exacerbations of COPD: a randomised controlled trial. Eur Respir J. 2007;29(5):906-913.

112. Petsky HL, Cates CJ, Lasserson TJ, et al. A systematic review and meta-analysis: tailoring asthma treatment on eosinophilic markers (exhaled nitric oxide or sputum eosinophils). Thorax. 2012;67(3): 199-208.

113. Baines KJ, Simpson JL, Wood LG, Scott RJ, Gibson PG. Transcriptional phenotypes of asthma defined by gene expression profiling of induced sputum samples. J Allergy Clin Immunol. 2011;127(1): 153-160, 160.e1-e9.

114. Gorska K, Krenke R, Korczynski P, Kosciuch J, Domagala-Kulawik J, Chazan R. Eosinophilic airway inflammation in chronic obstructive pulmonary disease and asthma. J Physiol Pharmacol. 2008; 59(Suppl 6):261-270.

115. McDonald VM, Gibson PG. Exacerbations of severe asthma. Clin Exp Allergy. 2012;42(5):670-677.

116. National Asthma Council Australia. Australian asthma handbook, Version 1.0. Melbourne: National Asthma Council Australia; 2014. Available from: http://www.asthmahandbook. org.au. Accessed March 20, 2014.

117. Chapman KR, Love L, Brubaker H. A comparison of breath-actuated and conventional metered-dose inhaler inhalation techniques in elderly subjects. Chest. 1993;104(5):1332-1337.

118. Connolly MJ. Inhaler technique of elderly patients: comparison of metered-dose inhalers and large volume spacer devices. Age Ageing. 1995;24(3):190-192.

119. Barrons R, Pegram A, Borries A. Inhaler device selection: special considerations in elderly patients with chronic obstructive pulmonary disease. Am J Health Syst Pharm. 2011;68(13):1221-1232.

120. Sovani MP, Whale CI, Oborne J, et al. Poor adherence with inhaled corticosteroids for asthma: can using a single inhaler containing budesonide and formoterol help? Br J Gen Pract. 2008;58(546):37-43.

121. Kew KM, Karner C, Mindus SM, Ferrara G. Combination formoterol and budesonide as maintenance and reliever therapy versus combination inhaler maintenance for chronic asthma in adults and children. Cochrane Database Syst Rev. 2013;12:CD009019.

122. Calverley PM, Anderson JA, Celli B, et al; TORCH investigators. Salmeterol and fluticasone propionate and survival in chronic obstructive pulmonary disease. $N$ Engl J Med. 2007;356(8):775-789.

123. Singh S, Loke YK. Risk of pneumonia associated with long-term use of inhaled corticosteroids in chronic obstructive pulmonary disease: a critical review and update. Curr Opin Pulm Med. 2010;16(2):118-122.

124. Manser R, Reid D, Abramson MJ. Corticosteroids for acute severe asthma in hospitalised patients. Cochrane Database Syst Rev. 2001;1: CD001740.

125. Walters JA, Gibson PG, Wood-Baker R, Hannay M, Walters EH. Systemic corticosteroids for acute exacerbations of chronic obstructive pulmonary disease. Cochrane Database Syst Rev. 2009;1: CD001288.

126. Leuppi JD, Schuetz P, Bingisser R, et al. Short-term vs conventional glucocorticoid therapy in acute exacerbations of chronic obstructive pulmonary disease: the REDUCE randomized clinical trial. JAMA. 2013;309(21):2223-2231.

127. McDonough AK, Curtis JR, Saag KG. The epidemiology of glucocorticoid-associated adverse events. Curr Opin Rheumatol. 2008;20(2):131-137.

128. Gibson PG, Powell H, Coughlan J, et al. Self-management education and regular practitioner review for adults with asthma. Cochrane Database Syst Rev. 2003;1:CD001117.

129. Abramson MJ, Bailey MJ, Couper FJ, et al; Victorian Asthma Mortality Study Group. Are asthma medications and management related to deaths from asthma. Am J Respir Crit Care Med. 2001;163(1):12-18. 
130. Zwerink M, Brusse-Keizer M, van der Valk PD, et al. Self management for patients with chronic obstructive pulmonary disease. Cochrane Database Syst Rev. 2014;3:CD002990.

131. Walters JA, Turnock AC, Walters EH, Wood-Baker R. Action plans with limited patient education only for exacerbations of chronic obstructive pulmonary disease. Cochrane Database Syst Rev. 2010;5:CD005074.

132. Friedlander AL, Lynch D, Dyar LA, Bowler RP. Phenotypes of chronic obstructive pulmonary disease. COPD. 2007;4(4):355-384.

133. Agusti A, Calverley PM, Celli B, et al; Evaluation of COPD Longitudinally to Identify Predictive Surrogate Endpoints (ECLIPSE) investigators. Characterisation of COPD heterogeneity in the ECLIPSE cohort. Respir Res. 2010;11:122.

134. Nadeem NJ, Taylor SJ, Eldridge SM. Withdrawal of inhaled corticosteroids in individuals with COPD - a systematic review and comment on trial methodology. Respir Res. 2011;12:107.

135. Magnussen H, Watz H, Kirsten A, et al. Stepwise withdrawal of inhaled corticosteroids in COPD patients receiving dual bronchodilation: WISDOM study design and rationale. Respir Med. 2014;108(4):593-599.

136. National Asthma Council Australia. Asthma Management Handbook 2006. Melbourne: National Asthma Council Australia; 2006. Available from: http://www.nationalasthma.org.au/uploads/handbook/370amh2006_web_5.pdf. Accessed March 20, 2014.

137. Chauhan BF, Ducharme FM. Anti-leukotriene agents compared to inhaled corticosteroids in the management of recurrent and/or chronic asthma in adults and children. Cochrane Database Syst Rev. 2012;5: CD002314.

138. Normansell R, Walker S, Milan SJ, Walters EH, Nair P. Omalizumab for asthma in adults and children. Cochrane Database Syst Rev. 2014(1):CD003559.

139. Haldar P, Brightling CE, Hargadon B, et al. Mepolizumab and exacerbations of refractory eosinophilic asthma. $N \mathrm{Engl} \mathrm{J} \mathrm{Med}$. 2009;360(10):973-984.

140. McDonald VM, Vertigan AE, Gibson PG. How to set up a severe asthma service. Respirology. 2011;16(6):900-911.

141. Stead LF, Hartmann-Boyce J, Perera R, Lancaster T. Telephone counselling for smoking cessation. Cochrane Database Syst Rev. 2013;8:CD002850.

142. Stead LF, Perera R, Bullen C, et al. Nicotine replacement therapy for smoking cessation. Cochrane Database Syst Rev. 2012;11 CD000146.

143. Hughes JR, Stead LF, Hartmann-Boyce J, Cahill K, Lancaster T. Antidepressants for smoking cessation. Cochrane Database Syst Rev. 2014; 1:CD000031

144. Cahill K, Stead LF, Lancaster T. Nicotine receptor partial agonists for smoking cessation. Cochrane Database Syst Rev. 2012;4: CD006103.

145. Stead LF, Lancaster T. Behavioural interventions as adjuncts to pharmacotherapy for smoking cessation. Cochrane Database Syst Rev. 2012;12:CD009670.

146. Thomas D, Abramson MJ, Bonevski B, et al. A pharmacist-led system-change smoking cessation intervention for smokers admitted to Australian public hospitals (GIVE UP FOR GOOD): study protocol for a randomised controlled trial. Trials. 2013;14:148.

147. Yohannes AM, Willgoss TG, Vestbo J. Tiotropium for treatment of stable COPD: a meta-analysis of clinically relevant outcomes. Respir Care. 2011;56(4):477-487.

148. Vogelmeier C, Hederer B, Glaab T, et al; POET-COPD Investigators. Tiotropium versus salmeterol for the prevention of exacerbations of COPD. N Engl J Med. 2011;364(12):1093-1103.

149. Tashkin DP, Celli B, Senn S, et al; UPLIFT Study Investigators. A 4-year trial of tiotropium in chronic obstructive pulmonary disease. N Engl J Med. 2008;359(15):1543-1554.

150. Kesten S, Jara M, Wentworth C, Lanes S. Pooled clinical trial analysis of tiotropium safety. Chest. 2006;130(6):1695-1703.

151. Kerstjens HA, Engel M, Dahl R, et al. Tiotropium in asthma poorly controlled with standard combination therapy. $N$ Engl J Med. 2012;367(13):1198-1207.
152. Befekadu E, Onofrei C, Colice GL. Tiotropium in asthma: a systematic review. J Asthma Allergy. 2014;7:11-21.

153. Lacasse Y, Brosseau L, Milne, et al. Pulmonary rehabilitation for chronic obstructive pulmonary disease. Cochrane Database Syst Rev. 2002;3:CD003793 [updated in Cochrane Database Syst Rev. 2006;4: CD003793].

154. Griffiths TL, Burr ML, Campbell IA, et al. Results at 1 year of outpatient multidisciplinary pulmonary rehabilitation: a randomised controlled trial. Lancet. 2000;355(9201):362-368.

155. Griffiths TL, Phillips CJ, Davies S, Burr ML, Campbell IA. Cost effectiveness of an outpatient multidisciplinary pulmonary rehabilitation programme. Thorax. 2001;56(10):779-784.

156. Turner S, Eastwood P, Cook A, Jenkins S. Improvements in symptoms and quality of life following exercise training in older adults with moderate/severe persistent asthma. Respiration. 2011;81(4): 302-310.

157. Blackstock FC, Webster KE, McDonald CF, Hill CJ. Comparable improvements achieved in chronic obstructive pulmonary disease through pulmonary rehabilitation with and without a structured educational intervention: a randomized controlled trial. Respirology. 2014;19(2):193-202.

158. Gibson PG, Powell H, Wilson A, et al. Self-management education and regular practitioner review for adults with asthma. Cochrane Database of Systematic Reviews. 2002;3:CD001117.

159. Trappenburg JC, Monninkhof EM, Bourbeau J, et al. Effect of an action plan with ongoing support by a case manager on exacerbation-related outcome in patients with COPD: a multicentre randomised controlled trial. Thorax. 2011;66(11):977-984.

160. Bischoff EW, Hamd DH, Sedeno M, et al. Effects of written action plan adherence on COPD exacerbation recovery. Thorax. 2011;66(1):26-31.

161. Bourbeau J, Julien M, Maltais F, et al; Chronic Obstructive Pulmonary Disease axis of the Respiratory Network Fonds de la Recherche en Santé du Québec. Reduction of hospital utilization in patients with chronic obstructive pulmonary disease: a diseasespecific self-management intervention. Arch Intern Med. 2003;163(5): 585-591.

162. Fan VS, Gaziano JM, Lew R, et al. A comprehensive care management program to prevent chronic obstructive pulmonary disease hospitalizations: a randomized, controlled trial. Ann Intern Med. 2012;156(10):673-683.

163. Chronic obstructive pulmonary disease: management of chronic obstructive pulmonary disease in adults in primary and secondary care (partial update) [webpage on the Internet]. Bethesda: National Institute for Health and Care Excellence. Available from: http://publications. nice.org.uk/chronic-obstructive-pulmonary-disease-cg101. Accessed March 20, 2014.

164. Moore RP, Berlowitz DJ, Denehy L, et al. A randomised trial of domiciliary, ambulatory oxygen in patients with COPD and dyspnoea but without resting hypoxaemia. Thorax. 2011;66(1):32-37.

165. Nonoyama ML, Brooks D, Guyatt GH, Goldstein RS. Effect of oxygen on health quality of life in patients with chronic obstructive pulmonary disease with transient exertional hypoxemia. Am J Respir Crit Care Med. 2007;176(4):343-349.

166. McKeon JL, Murree-Allen K, Saunders NA. Supplemental oxygen and quality of sleep in patients with chronic obstructive lung disease. Thorax. 1989;44(3):184-188.

167. Chaouat A, Weitzenblum E, Kessler R, et al. A randomized trial of nocturnal oxygen therapy in chronic obstructive pulmonary disease patients. Eur Respir J. 1999;14(5):1002-1008.

168. Fletcher EC, Luckett RA, Goodnight-White S, Miller CC, Qian W, Costarangos-Galarza C. A double-blind trial of nocturnal supplemental oxygen for sleep desaturation in patients with chronic obstructive pulmonary disease and a daytime $\mathrm{PaO} 2$ above $60 \mathrm{mmHg}$. Am Rev Respir Dis. 1992;145(5):1070-1076.

169. Dean MM. End-of-life care for COPD patients. Prim Care Respir J. 2008;17(1):46-50. 
170. Jennings AL, Davies AN, Higgins JP, Gibbs JS, Broadley KE. A systematic review of the use of opioids in the management of dyspnoea. Thorax. 2002;57(11):939-944.

171. McDonald VM, Higgins I, Gibson PG. Insight into older peoples' healthcare experiences with managing COPD, asthma, and asthma-COPD overlap. J Asthma. 2013;50(5):497-504.

172. Jones I, Kirby A, Ormiston P, et al. The needs of patients dying of chronic obstructive pulmonary disease in the community. Fam Pract. 2004;21(3):310-313.

173. Travers J, Marsh S, Caldwell B, et al. External validity of randomized controlled trials in COPD. Respir Med. 2007;101(6):1313-1320.
174. Wenzel SE. Asthma: defining of the persistent adult phenotypes. Lancet. 2006;368(9537):804-813.

175. Lange P. Persistent airway obstruction in asthma. Am J Respir Crit Care Med. 2013;187(1):1-2.

176. Beasley R, Weatherall M, Travers J, Shirtcliffe P. Time to define the disorders of the syndrome of COPD. Lancet. 2009;374(9691): 670-672.

177. Nelson HS, Weiss ST, Bleecker ER, Yancey SW, Dorinsky PM; SMART Study Group. The Salmeterol Multicenter Asthma Research Trial: a comparison of usual pharmacotherapy for asthma or usual pharmacotherapy plus salmeterol. Chest. 2006;129(1):15-26.

\section{Publish your work in this journal}

The International Journal of COPD is an international, peer-reviewed journal of therapeutics and pharmacology focusing on concise rapid reporting of clinical studies and reviews in COPD. Special focus is given to the pathophysiological processes underlying the disease, intervention programs, patient focused education, and self management protocols.

\section{Dovepress}

This journal is indexed on PubMed Central, MedLine and CAS. The manuscript management system is completely online and includes a very quick and fair peer-review system, which is all easy to use. Visit $\mathrm{http} / / / \mathrm{www}$.dovepress.com/testimonials.php to read real quotes from published authors.

Submit your manuscript here: http://www.dovepress.com/international-journal-of-copd-journal 